TITLE:

\title{
Effect of FK506 on osteoinduction by recombinant human bone morphogenetic protein-2.( Abstract_要旨 )
}

AUTHOR(S):

Kaihara, Shinji

CITATION:

Kaihara, Shinji. Effect of FK506 on osteoinduction by recombinant human bone morphogenetic protein-2.. 京都大学, 2003, 博士(医学)

ISSUE DATE:

2003-03-24

URL:

http://hdl.handle.net/2433/148767

RIGHT: 


\begin{tabular}{|c|c|}
\hline 名 & 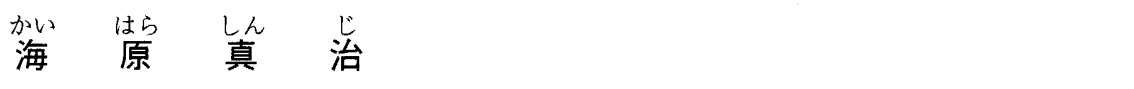 \\
\hline 学位(専攻分野) & 博 士（医 学） \\
\hline 学位記 番 号 & 論 医 博 第 1821 号 \\
\hline 学位授与の日付 & 平成 15 年 3 月 24 日 \\
\hline 学位授与の要件 & 学位規則第 4 条第 2 項該当 \\
\hline 学位論文題目 & $\begin{array}{l}\text { Effect of FK506 on osteoinduction by recombinant human bone mor- } \\
\text { phogenetic protein- } 2 \text {. } \\
\text { (組み換えヒト骨形成因子による骨誘導に掠けるFK506 の影響に関する研 } \\
\text { 究) } \\
\text { (主 查) }\end{array}$ \\
\hline
\end{tabular}

論文内容の要旨

目的：大腸菌由来リコンビナントヒト骨形成因子（ErhBMP-2）による骨誘導における免疫抑制郕 FK506 の影響につい て検索することを目的とした。FK506 は，現在移植の際に広く使われている免疫抑制剤である。近年ラットを使用した骨 移植モデルに扔いて，FK506 がその免疫抑制作用だけではなく，骨形成を促進する能力を有するという報告が散見される。 しかし，それらの報告は骨移植に際して骨伝導能のある担体を利用したものや，脱灰骨を移植したもので，純粋な骨誘導に 関する研究は現在のところなされていなかった。今回 ErhBMP-2によるin vivoでの骨誘導における FK506の影響につい て検索し，臨床での有用性，投与方法について検討した。

方法：120匹のウイスター系ラットを検定に用いた。右下腿部腓腹筋内にアテロコラーゲンタイプI コラーゲン（3 mg） を担体として使用し，ErhBMP-2（5 $\mu \mathrm{g} ）$ を挿入した。埋入 2 日前より FK506 (1 mg / kg，筋注，連日）投与した。各々 の群を短期投与群 (埋入 2 日前から埋入日まで), 中期投与群（埋入 2 日前から埋入 7 日目まで），長期投与群（埋入 2 日前 から屠殺まで）とし，コントロール群には生理食塩水を投与した。各群埋入 7 日目，14日目，21日目に埋入した下腿部腓腹 筋組織を採取し, 軟 X 線所見, 組織学的所見, 生化学的所見（アルカリフォスファターゼ (ALP) 活性, カルシゥム (Ca) 濃度)により骨誘導能を検討した。

結果：FK506 投与群は，コントロール群に比べて早期（7 日目）にALP 活性が高值を示した。しかし，埋入後14日目， 21日目の ALP 活性はコントロール群に比べて低值であった。また埋入後21日目での Ca 濃度はコントロール群が最も高值 であった。軟 X 線所見での不透過像は, Ca 濃度の変化と同様の所見を得た。病理組織学的所見では FK506 投与群はコン トロール群に比べ，骨芽細胞，破骨細胞ともに多く存在する傾向を認めた。

考察：現在，外傷，腫瘍などにより生じた広範な骨欠損に対する再建は，自家骨移植または，ハイドロキシアパタイト， チタンプレートなどの生体親和性のある人工物により行われている。しかし自家骨採取による手術侵襲を軽隇するため，骨 形成活性のある人工物の開発は重要である。その一つとして rhBMP-2 は近い将来臨床応用が期待されている。しかし， rhBMP-2 による骨再建は大量の rhBMP-2 が必要となり，現在のところ臨床で使用するには極めて高価である。一方， FK506 は大量投与，長期投与では骨梁の減少を促進し短期低量投与では骨形成促進効果があると報告されている。そこで FK506 が rhBMP-2 による骨再建の補助的な役割を果たすかどうかを検討した。本研究により，FK506 は短期間の投与で は初期の骨誘導を促進するが，長期投与では，骨誘導とともに骨吸収も促進した。また，長期投与では rhBMP-2 による骨 誘導が不十分であった。これはFK506 の副作用である血管収縮作用による血流不足に起因する酸素分圧の低下が原因と考 えられる。本研究により，FK506を骨誘導に効果的に利用するには投与量，投与期間の検討とともに，その副作用を制御 しなければ有効な結果は得られないと考えられた。

\section{論 文 審 查の結 果の 要旨}

今回, リコンビナントヒト骨形成因子（rhBMP-2）による骨誘導に扔ける免疫抑制剤 FK506 の影響について検討した。 
近年，ラットを使用した骨移植モデルにおいて FK506 がその免疫抑制作用だけではなく，骨形成を促進する能力を有する という報告が散見される。しかし，とれらの報告は骨移植に際して骨伝導能を有する担体を利用したものや，脱灰骨を移植 したもので, 純粋な骨誘導に関する研究はなされていなかった。今回 rhBMP-2 による骨誘導における FK506 の影響につ いて検討した。本研究により, FK506は短期間少量の投与で, 骨誘導を極めて効果的に促進することが判明した。一方, 長期投与では，骨誘導とともに骨吸収も促進することが判明した。また，長期投与では rhBMP-2 による誘導骨が質，量と もに不十分であった。rhBMP-2 は近い将来臨床応用が期待されているサイトカインである。しかし, rhBMP-2による骨 再建は大量の rhBMP-2 が必要となり，臨床で使用するには極めて高価である。本研究により FK506 は短期低量投与で, 骨形成促進効果があると確認された。そこでFK506 が rhBMP-2 による骨再建の補助的な役割を果たす可能性があり，臨 床応用に際する投与方法を示唆することが出来た。

以上の研究は, rhBMP-2 による骨誘導に対する FK506 の作用の解明に貢献し，臨床応用に寄与するところが多い。 したがって，本論文は博士 (医学) の学位論文として価值のあるものと認める。

なお，本学位授与申請者は，平成15年 2 月 25 日実施の論文内容とそれに関連した研究分野並びに学識確認のための試問を 受け，合格と認められたものである。 